\title{
Impact of winter fodder beet or kale allocation on body condition score gain and early lactation performance of dairy cows
}

\author{
Dawn E. DALLEY, J. Paul EDWARDS and Roshean R. WOODS* \\ DairyNZ, PO Box 85066, Lincoln University, Lincoln 7647, New Zealand \\ *Corresponding author: Roshean.Woods@dairynz.co.nz
}

\begin{abstract}
Forage crops such as fodder beet (FB) and kale are an important feature of dairy farming in Southland and Otago where winter pasture growth is negligible. However, farmers are concerned about poor performance of cows following winter FB feeding. In winter 2017, cows were offered FB or kale both with pasture baleage at two allocation rates: target (crop allocated to achieve a winter body condition score (BCS) gain of 0.7 ) or high (ad libitum crop). Diets with FB were lower in fibre, phosphorus, sulphur and calcium, but had a higher metabolizable energy, compared with kale diets. Body condition change and early lactation performance were monitored to compare effects of winter FB and kale diets. Average daily BCS gain before calving was similar for FB and kale cows. Crop type had a greater impact on cow performance than allocation rate. Cows wintered on FB had better reproductive performance (3-week pregnancy rate), and greater average milk solids, fat and protein yield $(\mathrm{kg} / \mathrm{d})$ than cows wintered on kale. Therefore, winter FB did not reduce cow performance compared with kale. However, the cumulative effects of a FB diet long term are yet to be determined and future research should monitor the impact on animal health.
\end{abstract}

Keywords: wintering, milk solids, nitrogen intake, minerals, reproduction

\section{Introduction}

Dairy farming in Southland and Otago has grown in the past 20 years from 282,900 cows on 769 farms in 1998-99 to 861,733 cows on 1430 farms producing $18.6 \%$ of New Zealand's (NZ) milk solids (MS) in 2018-19 (LIC 1999; LIC \& DairyNZ 2019). In these regions the use of forage crops such as fodder beet (FB; Beta vulgaris L.) and brassicas such as kale (Brassica oleracea L.) are an important aspect of farming (Nicol et al. 2003; Dalley 2010), particularly to fill feed deficits during the cool winter months when pasture growth is negligible (Dalley \& Geddes 2012). The reliable fastgrowing characteristics of such crops mean that highquality, readily digestible feed can be produced within a wide range of climatic conditions and utilised during winter to meet body condition score (BCS) targets at calving of 5 to 5.5 (10-point scale; Roche et al. 2009).
Potential environmental benefits of FB are also being investigated because of its low protein content which can reduce dietary nitrogen $(\mathrm{N})$ intake and subsequent urine-N excretion (Waghorn et al. 2019).

The use of FB in southern regions increased exponentially between 2005 and 2018 and it was common practice to offer ad libitum fodder beet with minimal forage supplement (Gibbs et al. 2015). However, farmers are becoming increasingly concerned about poorer than expected performance post-calving of their cows following autumn and winter FB feeding (Edwards et al. in press) so the area planted has declined in the past two years (H.G. Judson pers. comm.). Perceived issues include: lower than expected milk production based on BCS at calving and levels of feeding in early lactation; the unknown impact of FB feeding on lifetime performance; reproductive performance; and links with metabolic disease (including acidosis).

Fodder beet bulbs are low in crude protein (CP), neutral detergent fibre (NDF), phosphorus (P) and calcium (Ca) (Dalley et al. 2017; Waghorn et al. 2018). At the time of grazing, FB bulbs usually make up over $80 \%$ of the FB offered, which means when FB comprises a large proportion of the diet, it may not supply the recommended daily intake of these nutrients. These imbalances can reduce animal production and impair animal health (Grace et al. 2010). For example, a diet containing $85 \% \mathrm{FB}$ and the remainder being barley straw provides inadequate nutrition for non-lactating cows and a leads to a high incidence of acidosis (Waghorn et al. 2018).

The aim of this study was to compare BCS gain, nutrient intake and early lactation milk production of groups of cows offered two feeding levels of winter diets differing in crop type (FB and kale). It was hypothesised that there would be a crop $\times$ allocation interaction where cows fed ad libitum FB would become over conditioned and this would lead to poorer animal performance in early lactation.

\section{Materials and Methods}

\section{Location and experimental design}

This systems study was conducted at the Southern Dairy Hub (Southland, NZ 46 18'37.8'S, 168 $18^{\circ} 46.1$ 'E, $11 \mathrm{~m}$ a.s.l.) in 2017. It involved a winter-feeding trial in 
June-August 2017, and subsequent monitoring of cows in early lactation.

The winter-feeding trial compared FB and kale, each provided at two different allocation rates: 'target' and 'high'. Allocations were determined using DairyNZ's winter crop allocation calculator (DairyNZ 2015) based on the quality of each feed and expected utilisation. Feed was allocated to the 'target' group to achieve an average BCS gain of 0.7 over winter through a metabolisable energy (ME) intake of $140 \mathrm{MJ} \mathrm{ME/cow/d} \mathrm{to} \mathrm{meet} \mathrm{a}$ BCS target of 5 at calving. For this group, the crop was offered at a maximum of $70 \%$ of total feed allocation (on a dry matter (DM) basis), with the remainder being pasture baleage. For the 'high' group, crop constituted at least $80 \%$ of total diet and was offered ad libitum with the remainder being pasture baleage. Predicted $\mathrm{BCS}$ gain and $\mathrm{ME}$ intake for the high group were 1.25 and $160 \mathrm{MJ} \mathrm{ME} / \mathrm{cow} / \mathrm{d}$, respectively.

\section{Animals and feeding}

A total of 328 mixed-aged pregnant Friesian $\times$ Jersey cross cows were selected for the experiment. This was the first season since the establishment of the Southern Dairy Hub. The majority ( $80 \%)$ of cows sourced were naïve to winter crop and had a planned start of calving of 20 July 2017 although the actual mean calving date was later than this. Eighty-two cows were assigned to each treatment group to achieve a balance for BCS (mean 4.6), calving date (mean 24 August 2017), breeding worth (BW; mean 113), production worth (mean 88), source and age (mean 4.6 years). Cows began transitioning onto their respective crops on 31 May 2017 where they remained until they were drafted into the springer herd 10 days before calving. Transitioning onto FB followed best practice management (Gibbs 2014), whereby FB feeding started at $1 \mathrm{~kg} \mathrm{DM} / \mathrm{cow} / \mathrm{d}$ and increased by $1 \mathrm{~kg}$ DM every second day. The amount of baleage offered decreased as the crop allocation increased. The FB-high cows took 30 days to reach their maximum allocation of FB (11.9 kg DM/cow/d), whereas the FB-target cows took 24 days to transition onto their lower allocation of FB (9.1 kg DM/cow/d). Transitioning onto kale followed recommendations in Nicol et al. (2003) with the amount offered increasing $1 \mathrm{~kg}$ DM each day for the first ten days. Cows in the kale-high treatment took 14 days to reach their maximum allocation of kale $(14 \mathrm{~kg}$ $\mathrm{DM} /$ cow/d) whereas the kale-target cows took 12 days to reach their maximum kale allocation $(10.5 \mathrm{~kg} \mathrm{DM} /$ cow/d). Due to each group being balanced for calving date, the difference in time taken to transition onto crop meant that the FB-high cows were on their full allocation of FB for an average of 55 days, FB-target for 62 days, kale-high for 74 days and kale-target for 73 days, despite all groups starting their crop allocation on the same day. After calving, cows continued to be monitored but were split evenly between four farmlet herds for lactation and managed using the same decision rules.

\section{Crop establishment}

Fodder beet (cultivar Vermon, Agricom Ltd, Lincoln, NZ) was sown at a rate of 80,000 seeds/ha on 22 November 2016; total fertiliser inputs were $194 \mathrm{~kg} \mathrm{~N} /$ ha, $51 \mathrm{~kg} \mathrm{P} / \mathrm{ha}, 100 \mathrm{~kg} \mathrm{~K} / \mathrm{ha}, 25 \mathrm{~kg} \mathrm{~S} / \mathrm{ha}$. Kale (cultivar Regal $^{\circledR}$, PGG Wrightson Seeds, Lincoln, NZ) was sown at a rate of $4 \mathrm{~kg}$ seed/ha on 26 November 2016; total fertiliser inputs were $155 \mathrm{~kg} \mathrm{~N} / \mathrm{ha}, 35 \mathrm{~kg} \mathrm{P} / \mathrm{ha}, 13 \mathrm{~kg}$ $\mathrm{K} / \mathrm{ha}, 2 \mathrm{~kg} \mathrm{~S} / \mathrm{ha}$. Fertiliser use was informed by soil test results from samples collected (to $150 \mathrm{~mm}$ ) from crop paddocks on 1 October 2016 (data not presented) and along with herbicide and insecticide were applied as recommended by the seed company's Technical Field Representative. All paddocks were previously in pasture grazed by sheep.

\section{Crop and supplement measurements}

Crop yields were determined fortnightly and used to calculate the area of the feeding break. For kale, three $1 \mathrm{~m}^{2}$ quadrats were randomly selected from the area to be grazed over the next two weeks. All plants from within the quadrat were cut to ground level and weighed. Representative plants were sub-sampled for DM, quality and mineral analysis. For FB, yield was assessed from three $4 \mathrm{~m}$ double rows of crop in the next area of the paddock to be grazed. All FB plants were pulled from the ground, soil removed, and the fresh weight of leaf and bulb recorded separately. A longitudinal wedge was taken from at least four bulbs representative of the range in bulb size of the entire sample and leaves from these four plants were collected for DM, quality and mineral analysis. Subsamples of baleage from each paddock were collected fortnightly from the next batch to be fed. Where more than one bale was sampled, these subsamples from each were bulked prior to DM, quality and mineral analysis.

Dry matter content for crop yields was determined by drying at $95^{\circ} \mathrm{C}$ for at least 48 hours. Crop and supplement feed quality and mineral analysis was conducted by Hill Laboratories (Hamilton, NZ). Samples were oven dried at $62^{\circ} \mathrm{C}$, ground to $1 \mathrm{~mm}$ and feed quality estimated by near infrared spectroscopy (MPA FT-NIR Analyzer, Bruker Optics, Billerica, MA). Metabolisable energy was derived from dry organic matter digestibility (DOMD) using the following calculation $\mathrm{ME}=0.16 \mathrm{DOMD}$. The phosphorus, potassium $(\mathrm{K})$, sulphur $(\mathrm{S})$, calcium $(\mathrm{Ca})$, magnesium $(\mathrm{Mg})$, sodium $(\mathrm{Na})$, iron $(\mathrm{Fe})$, manganese $(\mathrm{Mn})$, zinc $(\mathrm{Zn})$, copper $(\mathrm{Cu})$ and boron $(\mathrm{B})$ content of DM was analysed by ICP-OES, while the molybdenum (Mo), cobalt (Co) and selenium (Se) content was analysed by ICP-MS following nitric acid/hydrogen peroxide digestion. 


\section{Animal performance}

Body condition score ( $0-10$ scale) (Roche et al. 2009) of all cows was recorded on 29 May 2017 before transitioning onto the winter crops and then fortnightly thereafter. Immediately prior to the first milking, foremilk samples were collected from each quarter of all cows and colostrum quality determined using a Brix refractometer (Brix/RI-Chek, Reichert Analytical Instruments, Depew, NY, USA). Any quarters where suckling was evident were noted. Milk weights $(\mathrm{kg})$ were recorded for each cow at every milking using the DeLaval DelPro ${ }^{\mathrm{TM}}$ Herd Management software and milk meters in the dairy. Milk samples were collected at an afternoon and following morning milking every fortnight until December, and monthly thereafter. Milk composition of these samples (percentage protein, fat, lactose, and somatic cell count (SCC)) for each cow was measured as part of the Livestock Improvement Corporation's (LIC) herd testing service using a Milkoscan milk analyser (Foss Electric Hillerød, Denmark). Full lactation production data were determined by calculation using the recorded milk weights from the milk meters averaged by week and the herd test composition data for each cow.

Mating via artificial insemination (AI) occurred between 27 Oct 2017 and 8 Dec 2017 using tail paint to identify animals on heat at the morning milking; after this, bulls were run with the herd. Each AI mating was recorded for each cow. Cows were pregnancy scanned on 25 Jan 2018, and some cows rechecked on 1 Mar 2018. This allowed for calculation of 3-and 6 -week submission rate and pregnancy rate, and the number of conceptions to the first $\mathrm{AI}$ as an indication of reproduction performance.

\section{Statistical analyses}

All analyses were performed using SAS/STAT 15.1 (SAS Institute Inc., Cary, NC, USA). Feed quality and mineral levels for feed components (FB leaf, FB bulb, kale, baleage) were analysed by one-way ANOVA with feed component as a fixed effect. Dietary intakes of these feed parameters were analysed using a two-way ANOVA with crop (FB, kale), allocation (high, target), and their interaction included in the model as fixed effects.

Fortnightly BCS data between 29 May 2017 and week 12 of lactation, and weekly production data (milk volume, fat $\%$, protein $\%$, MS $\%$, fat yield, protein yield, MS yield, SCC) for the first 12 weeks in lactation (relative to calving date) were analysed using mixed models approach to repeated measures ANOVA (Proc Mixed). The models included crop, allocation, week relative to calving, and all their interactions as fixed effects, number of days between 1 June and calving, and BW as covariates, source (where animals came from) and age group (two year olds, three and four year olds, and cows five years or older) as blocking factors, and cow as random factor. The covariance pattern model used was first order autoregressive. Full lactation production data were analysed using ANOVA and included crop, allocation and their interaction as fixed effects, number of days between 1 June and calving, lactation length, and BW as covariates, source and age group as blocking factors.

Linear regression was used to determine the average weekly BCS change between: 29 May 2017 and calving, calving to week six of lactation, and week six to week 12 of lactation, and the slopes analysed separately for each time period. The model included crop, allocation, and their interaction as fixed effects, BCS on 29 May 2017 as covariate, as well as covariates and blocking factors as above.

Colostrum quality (Brix) data were analysed as weighted repeated measures ANOVA. The model used was similar to that for production, but with quarters repeated within cow. Cows with more than one quarter suckled were excluded from the analysis, and the number of non-suckled quarters was used as weighting variable. The covariance pattern model was compound symmetry.

Binary outcomes for reproduction (3- and 6-week submission, and pregnancy rates, conception to first AI and final pregnancy rate) were analysed using binary logistic regression (Proc Glimmix, SAS/STAT 15.1, SAS Institute Inc, Cary, NC, USA). Days to first $\mathrm{AI}$ and conception (from calving or start of mating) were analysed using a Cox proportional hazard model (Proc Phreg, SAS/STAT 15.1, SAS Institute Inc, Cary, NC, USA). In addition to crop, allocation, and their interaction, the model included the same covariates and blocking factors as above.

Tukey's method was used for pairwise comparisons and significance declared if $P \leq 0.05$. Adjusted means are presented and standard error of the difference (SED). For binary data, group differences are also presented as relative risk (RR) and $95 \%$ confidence interval (CI). Data were $\log 10$ transformed if required to achieve homogeneity of variance of the residuals.

\section{Results}

\section{Feed and crop}

Winter diet allocation and utilisation for each treatment is presented in Table 1. Mean crop DM yields throughout the grazing period were $23 \mathrm{t} \mathrm{DM} / \mathrm{ha}$ for FB and $14 \mathrm{t} \mathrm{DM} / \mathrm{ha}$ for kale. The proportion of FB bulb started at $72 \%$ in June and rose to $82 \%$ by mid-August. Composition of the individual feed components (FB bulb, FB leaf, kale and baleage) is presented in Table 2. Fodder beet bulbs had significantly lower levels of $\mathrm{CP}$, acid detergent fibre (ADF), NDF, ash, N, P, S and Ca, 
Table 1 Allocation and utilisation of fodder beet (FB) or kale fed at two levels (high, target) to mixed-age pregnant cows during winter.

\begin{tabular}{lcccc}
\hline & FB' - high & FB'- target & Kale-high & Kale-target \\
\hline Crop allocation (kg DM/cow/d) & 11.9 & 9.1 & 14 & 10.5 \\
Utilisation of crop (\%) & 90 & 90 & 80 & 85 \\
Baleage allocation (kg DM/cow/d) & 3 & 4.5 & 3 & 4.5 \\
Assumed utilisation of baleage (\%) & 85 & 85 & 85 & 85 \\
Dry matter intake (kg DM/cow/d) & 13.3 & 153 & 13.8 & 12.8 \\
Metabolizable energy intake (MJ/d) & 176 & 157 & 147 \\
\hline
\end{tabular}

${ }^{1}$ Fodder beet crops had an average of $72 \%$ bulb in June, $75 \%$ bulb in July, and $82 \%$ bulb in August.

Table 2 Mean composition of fodder beet (FB) bulb and leaf, kale, and pasture baleage eaten by mixed-age non-lactating dairy during winter. Means with the same letter (a-d) within a row are not significantly different at the $5 \%$ level. SED = standard error of the difference.

\begin{tabular}{|c|c|c|c|c|c|c|}
\hline & $\begin{array}{c}\text { FB bulb } \\
n=6\end{array}$ & $\begin{array}{c}\text { FB leaf } \\
n=6\end{array}$ & $\begin{array}{c}\text { Kale } \\
n=6\end{array}$ & $\begin{array}{c}\text { Baleage } \\
n=12\end{array}$ & SED & $P$ value \\
\hline Dry matter (\%) & $18.7^{\mathrm{b}}$ & $10.5^{\mathrm{c}}$ & $13.2^{\mathrm{bc}}$ & $38.5^{a}$ & 2.18 & $<0.001$ \\
\hline Crude protein (\% DM) & $9.1^{\mathrm{c}}$ & $22.6^{\mathrm{a}}$ & $15.6^{\mathrm{b}}$ & $12.9^{b}$ & 1.27 & $<0.001$ \\
\hline Acid detergent fibre (\% DM) & $5.6^{d}$ & $14.6^{\mathrm{c}}$ & $22.8^{\mathrm{b}}$ & $30.1^{\mathrm{a}}$ & 0.89 & $<0.001$ \\
\hline Neutral detergent fibre (\% DM) & $9.3^{\mathrm{c}}$ & $27.0^{\mathrm{b}}$ & $27.1^{\mathrm{b}}$ & $47.6^{a}$ & 1.41 & $<0.001$ \\
\hline Organic matter (\% DM) & $95.2^{\mathrm{a}}$ & $85.5^{d}$ & $90.0^{c}$ & $92.1^{\mathrm{b}}$ & 0.58 & $<0.001$ \\
\hline Ash (\% DM) & $4.8^{\mathrm{d}}$ & $14.5^{\mathrm{a}}$ & $10.0^{\mathrm{b}}$ & $8.0^{\mathrm{c}}$ & 0.58 & $<0.001$ \\
\hline Digestibility of organic matter in dry matter (\%) & $91.7^{\mathrm{a}}$ & $73.1^{\mathrm{b}}$ & $73.9^{b}$ & $64.6^{c}$ & 1.40 & $<0.001$ \\
\hline Soluble sugars (\% DM) & $65.7^{\mathrm{a}}$ & $20.3^{b}$ & $21.9^{b}$ & $8.6^{c}$ & 1.84 & $<0.001$ \\
\hline Metabolizable energy (MJ/kg) & $14.7^{\mathrm{a}}$ & $11.7^{\mathrm{b}}$ & $11.9^{\mathrm{b}}$ & $10.3^{c}$ & 0.23 & $<0.001$ \\
\hline Nitrogen (\% DM) & $1.47^{\mathrm{c}}$ & $3.62^{\mathrm{a}}$ & $2.52^{\mathrm{b}}$ & $2.07^{\mathrm{b}}$ & 0.208 & $<0.001$ \\
\hline Phosphorus (\% DM) & $0.11^{\mathrm{b}}$ & $0.32^{\mathrm{a}}$ & $0.29^{a}$ & $0.33^{a}$ & 0.018 & $<0.001$ \\
\hline Potassium (\% DM) & $1.63^{\mathrm{b}}$ & $4.06^{\mathrm{a}}$ & $2.63^{b}$ & $1.92^{\mathrm{b}}$ & 0.342 & $<0.001$ \\
\hline Sulphur (\% DM) & $0.08^{c}$ & $0.26^{b}$ & $0.70^{\mathrm{a}}$ & $0.27^{b}$ & 0.034 & $<0.001$ \\
\hline Calcium (\% DM) & $0.14^{\mathrm{c}}$ & $0.68^{\mathrm{b}}$ & $1.52^{\mathrm{a}}$ & $0.73^{b}$ & 0.089 & $<0.001$ \\
\hline Magnesium (\% DM) & $0.16^{\mathrm{b}}$ & $0.38^{\mathrm{a}}$ & $0.19^{b}$ & $0.20^{\mathrm{b}}$ & 0.018 & $<0.001$ \\
\hline Sodium (\% DM) & $0.38^{\mathrm{b}}$ & $1.45^{\mathrm{a}}$ & $0.48^{\mathrm{b}}$ & $0.53^{b}$ & 0.143 & $<0.001$ \\
\hline Iron (mg/kg) & $152^{b}$ & $965^{\mathrm{a}}$ & $693^{\mathrm{ab}}$ & $276^{b}$ & 196.0 & 0.020 \\
\hline Manganese (mg/kg) & $55.8^{\mathrm{ab}}$ & $134.0^{\mathrm{a}}$ & $27.7^{\mathrm{b}}$ & $139.5^{\mathrm{a}}$ & 25.17 & 0.005 \\
\hline Zinc $(\mathrm{mg} / \mathrm{kg})$ & $34.5^{\mathrm{ab}}$ & $63.3^{\mathrm{a}}$ & $19.0^{b}$ & $21.3^{\mathrm{b}}$ & 11.05 & 0.026 \\
\hline Copper (mg/kg) & $3.3^{c}$ & $9.3^{\mathrm{a}}$ & $3.3^{c}$ & $5.9^{b}$ & 0.54 & $<0.001$ \\
\hline Boron (mg/kg) & $11.5^{\mathrm{c}}$ & $28.0^{\mathrm{a}}$ & $24.3^{b}$ & $7.1^{d}$ & 0.96 & $<0.001$ \\
\hline Molybdenum (mg/kg) & $0.03^{c}$ & $0.24^{b c}$ & $0.64^{\mathrm{a}}$ & $0.38^{a b}$ & 0.081 & $<0.001$ \\
\hline Cobalt $(\mathrm{mg} / \mathrm{kg})$ & $0.06^{\mathrm{a}}$ & $0.28^{a}$ & $0.20^{\mathrm{a}}$ & $0.11^{\mathrm{a}}$ & 0.057 & 0.049 \\
\hline Selenium (mg/kg) & $0.02^{\mathrm{a}}$ & $0.04^{\mathrm{a}}$ & $0.04^{a}$ & $0.03^{a}$ & 0.006 & 0.026 \\
\hline
\end{tabular}

but significantly higher levels of soluble sugars, organic matter (OM), DOMD and ME compared to the other feed components. Copper levels were low in both FB bulbs and kale.

The composition of key nutrients in the diet, based on allocation and utilisation of each feed component for each treatment (Table 1) is presented in Table 3. There were no significant crop $\times$ allocation interactions, except for NDF $(\mathrm{P}=0.042)$. However, there was a significant effect of crop for DM, ADF, NDF, soluble sugars, OM, Ash, DOMD, ME, P, S, Ca, B and Mo across allocation levels $(\mathrm{P}<0.05)$. Although dietary $\mathrm{CP}$ and $\mathrm{N}$ levels in the FB treatments appear to be lower than for kale, the effect of crop was not significant at the $5 \%$ level. The effect of crop on $\mathrm{N}$ intake $(\mathrm{g} \mathrm{N} /$ cow/d) was also not significant $(\mathrm{P}=0.074)$, although 
Table 3 Composition of total diets offered to mixed-age, pregnant cows during winter in all combinations of two crop (fodder beet, FB; kale) and two allocation (high; low) treatments. SED = standard error of the difference.

\begin{tabular}{lccccccc}
\hline & FB-high & FB-target & Kale-high & Kale-target & SED & $\begin{array}{c}\text { P value } \\
\text { crop }\end{array}$ & $\begin{array}{c}\text { P value } \\
\text { allocation }\end{array}$ \\
\hline Nitrogen (g N/cow/d) & 270 & 247 & 331 & 301 & 39.6 & 0.074 & $\mathrm{~ns}$ \\
Crude protein (\% DM) & 12.6 & 13.0 & 14.9 & 14.6 & 1.75 & $\mathrm{~ns}$ & $\mathrm{~ns}$ \\
Neutral detergent fibre (\% DM) & 19.4 & 25.1 & 31.8 & 32.6 & 1.44 & $<0.001$ & 0.013 \\
Soluble sugars (\% DM) & 46.4 & 39.2 & 20.0 & 17.7 & 2.22 & $<0.001$ & 0.016 \\
Metabolizable energy (MJ/kg) & 13.2 & 12.8 & 11.4 & 11.6 & 0.23 & $<0.001$ & $\mathrm{~ns}$ \\
Phosphorus (\% DM) & 0.19 & 0.22 & 0.29 & 0.31 & 0.013 & $<0.001$ & 0.042 \\
Sulphur (\% DM) & 0.14 & 0.17 & 0.58 & 0.62 & 0.057 & $<0.001$ & $\mathrm{~ns}$ \\
Calcium (\% DM) & 0.39 & 0.38 & 1.32 & 1.33 & 0.087 & $<0.001$ & $\mathrm{~ns}$ \\
Magnesium (\% DM) & 0.21 & 0.22 & 0.18 & 0.21 & 0.020 & $\mathrm{~ns}$ & $\mathrm{~ns}$ \\
\hline
\end{tabular}

there was a trend for lower intakes with FB treatments. There was a significant main effect of allocation (across crop) on DM, NDF, soluble sugars, $\mathrm{P}$ and $\mathrm{B}(\mathrm{P}<0.05)$; $\mathrm{B}$ and soluble sugars were increased in the high allocation diets, while DM, NDF and P were decreased.

\section{Body condition score}

Mean BCS for each treatment from the start of winter to 12 weeks into lactation is shown in Figure 1. Overall mean BCS was higher for FB cows than kale cows (4.8 vs 4.7 , respectively, $\mathrm{P}=0.017$ ). The later a cow calved, the higher the BCS by approximately $0.05 \mathrm{BCS}$

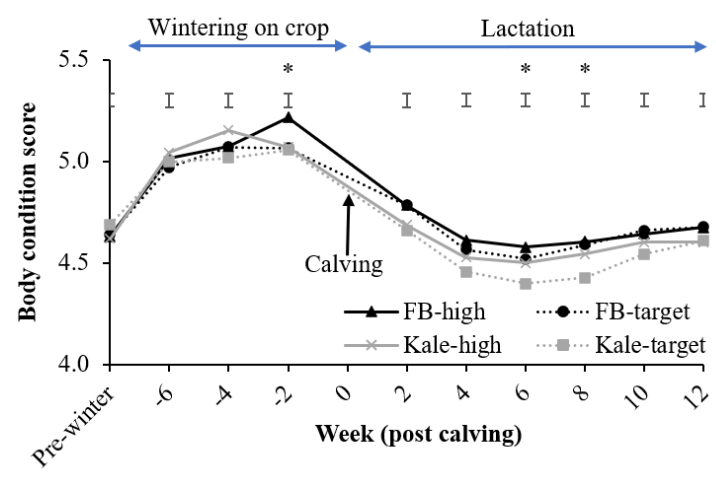

Figure 1 Average body condition score before crop wintering i.e. 'Pre-winter' (29 May 2017) and then fortnightly relative to individual cow calving date (week 0 ) of mixed-age pregnant cows during the winter grazing of fodder beet (FB) or kale crops and the first 12 weeks of lactation. Crops were fed with pasture baleage at two different allocation rates: 'high' (at least $80 \%$ crop, offered to ad libitum) and 'target' (a maximum of $70 \%$ crop offered). Note: calving date $=$ week $0,2=$ BCS within 1 to 14 days pre-calving, and $2=\operatorname{BCS} 1$ to 14 days post calving etc. Error bars are 1 standard error of the difference (SED); ${ }^{*} \mathrm{P}<0.05$. points per 10 days later calving. Average weekly BCS gain between 29 May 2017 and calving was similar for cows on FB and kale, however, cows on the high allocation had a greater average weekly BCS gain of 0.047 , compared with 0.038 for those on the target allocation $(\mathrm{P}=0.003)$. Body condition score loss in the first six weeks of lactation was similar for all cows regardless of crop or allocation treatments with a mean weekly BCS loss of 0.050. Similarly, BCS gains in weeks six to 12 of lactation were not affected by crop or allocation treatments with a mean weekly BCS gain of 0.028

\section{Colostrum quality and milk production}

After calving, colostrum Brix (an indicator of colostrum quality) was similar for all cows with treatment means ranging from 22.6 to $23.7^{\circ} \mathrm{Bx}\left(1^{\circ} \mathrm{Bx}\right.$ equivalent to $1 \mathrm{~g}$ sucrose in $100 \mathrm{~g}$ of solution).

Milk production data are presented relative to calving date for the first 12 weeks of lactation. There was no effect of allocation on any of the milk production parameters measured. There was a significant crop $\times$ allocation $\times$ week interaction for MS yield $(\mathrm{kg} / \mathrm{d})$ $\mathrm{P}=0.014$ ) with a trend for the FB-high treatment to have greater MS yield ( $\mathrm{P}=0.014$; Figure 2). This was significantly greater than the kale-high treatment for weeks two to eight of lactation. Accordingly, average daily MS yield $(\mathrm{kg} / \mathrm{d})$ was significantly greater for cows wintered on FB than for cows wintered on kale $(1.93 \mathrm{~kg}$ $\mathrm{MS} / \mathrm{d}$ vs $1.86 \mathrm{~kg} \mathrm{MS} / \mathrm{d}$, respectively; $\mathrm{P}=0.002$ ).

There was no significant difference in fat content (4.6-4.7\%), protein content (3.8-3.9\%) or SCC (median of 35,000$)$ between crop and allocation treatments. However, there was a significant crop $\times$ allocation $\times$ time interaction $(\mathrm{P}=0.014)$ for fat yield $(\mathrm{kg} / \mathrm{d})$ with a trend for greater fat yields for the FB-high treatment; these were significantly greater for weeks three to eight of lactation compared with the kale-high treatment. 


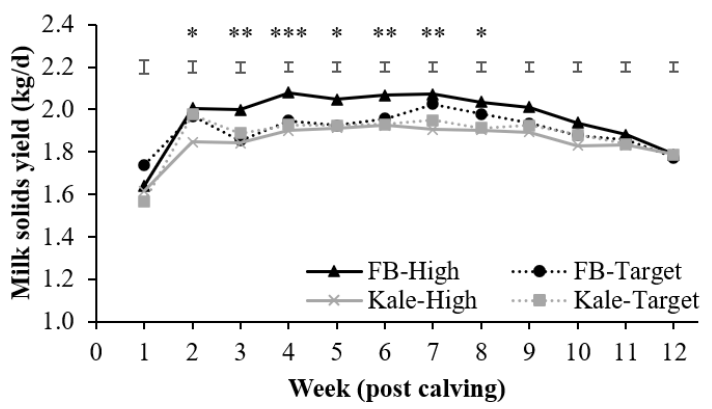

Figure 2 Milk solids yield $(\mathrm{kg} / \mathrm{d})$ of mixed-age cows for the first 12 weeks of lactation following winter grazing of fodder beet (FB) or kale fed at two different allocation rates: 'high' (at least $80 \%$ crop, offered ad libitum, with pasture baleage) and 'target' (a maximum of $70 \%$ crop offered, with pasture baleage). Error bars are 1 standard error of the difference (SED). ${ }^{*} \mathrm{P}<0.05,{ }^{* *} \mathrm{P}<0.01$, ${ }^{* * *} \mathrm{P}<0.001$.

Similarly, there was a trend for protein yield $(\mathrm{kg} / \mathrm{d})$ to be greatest in the FB-high treatment; significantly greater than the kale-high treatment in weeks two, three, four and seven $(\mathrm{P}=0.020)$. Average daily fat and protein yields were greater for cows wintered on FB than for cows wintered on kale (1.06 vs $1.02 \mathrm{~kg}$ fat $/ \mathrm{d}$ and $0.87 \mathrm{vs} 0.85 \mathrm{~kg}$ protein $/$, respectively; $\mathrm{P}<0.01$ ). By week 10 , there were no differences between treatments for milk production parameters.

For the full lactation, there was a significant effect of crop $(\mathrm{P}<0.05)$ on total MS, fat ( $245 \mathrm{vs} 236 \mathrm{~kg}$; SED 6.2) and protein (205 vs $197 \mathrm{~kg}$; SED 4.8) yield for cows wintered on FB or kale, respectively. There was no effect of allocation or crop $\times$ allocation interaction.

\section{Reproductive performance}

Crop affected 3-week pregnancy rate $(\mathrm{P}=0.011)$; this was $73 \%$ for cows wintered on $\mathrm{FB}$, compared with $59 \%$ for cows wintered on kale. The FB cows had 15\% greater chance of being pregnant after three weeks of mating, compared to cows wintered on kale ( $R R=1.15$, 95\% CI 1.04-1.22). After six weeks of mating, these were not significantly different.

Crop also affected the conception rate to the first AI $(\mathrm{P}=0.007)$; cows wintered on $\mathrm{FB}$ had $17 \%$ greater chance ( $\mathrm{RR}=1.17,95 \% \mathrm{CI} 1.05-1.26)$ of conceiving to the first $\mathrm{AI}(70 \%$ conception rate to first $\mathrm{AI})$ than cows wintered on kale ( $54 \%$ conception rate to first AI). There was a significant crop $\times$ allocation interaction for final pregnancy rate $(\mathrm{P}=0.040)$; cows wintered on the FB-target treatment tended to have a higher pregnancy rate, compared with those wintered on the FB-high treatment $(99.0 \%$ vs $93.6 \%$, respectively). Whereas for kale, those wintered on the kale-target treatment tended to have a lower pregnancy rate than the kale- high cows $(93.6 \%$ vs $97.0 \%$, respectively). There was a significant effect of calving date for 3 -week pregnancy rate $(\mathrm{P}=0.001)$, and conception to the first AI $(\mathrm{P}=0.049)$. Later calving cows were less likely to conceive or be pregnant. There was no effect of crop or allocation on 3-week and 6-week submission rate and 6-week pregnancy rate.

Time from start of mating to conception was less for cows wintered on FB compared with kale (median time to conception 13.5 vs 17.5 days, $\mathrm{P}=0.044$ ). There was no significant interaction between crop and allocation and no effect of allocation on time from start of mating to conception.

\section{Discussion}

\section{Animal performance}

Based on the results of this study we reject our hypothesis. Cows fed ad libitum FB were not over conditioned (Figure 1) and FB cows had greater milk production and improved reproductive performance, compared with kale cows. An unexpected result was the lack of difference in milk production and reproductive performance between the two levels of crop allocation. A factor that is likely to have contributed to this was the shorter than usual period of time on winter crop treatments due to the early calving dates of the majority of the cows, which meant they were taken off crop and drafted into the springer herd earlier. These cows (which made up $80 \%$ of the groups) were also naïve to crop, which meant it took a long time to transition and reach full crop allocation, particularly for the FB cows. The effect of transition time is supported by the higher BCS gain shown for later calving cows. Further, the change from a North Island planned start of calving (20 July) to a South Island planned start of calving (5 August), meant the cows had an additional 16 days to cycle. This was likely a contributing factor for the high pregnancy rates observed in this study.

Milk solids yield was greater for cows wintered on FB than on kale. Keogh et al. (2009) also observed increased MS production when cows were fed $63-64 \%$ FB plus baled silage compared with cows offered 63$64 \%$ kale or an all grass silage diet indoors. Increases in fat composition $(\mathrm{g} / \mathrm{kg})$, and fat yield $(\mathrm{kg} / \mathrm{d})$ were also shown in the same study for winter FB diets compared with kale. In the current study although fat composition (\%) was not affected, fat yield $(\mathrm{kg} / \mathrm{d})$ increased with FB diets, likely driven by milk yield. These increases in MS yield and fat yield with FB were only apparent up to week eight of lactation which is comparable to Keogh et al. (2009); however, the current study monitored milk production over a longer period (12 weeks) as well as total lactation. The difference in cumulative MS production between FB 
and kale observed in the first 12 weeks of lactation was still evident at the end of the season, indicating that there was no compensatory MS production from the kale cows later in lactation.

Cows wintered on FB and kale had similar BCS gain over the pre-calving period (although none of the treatment groups achieved their target or predicted BCS gain). This is similar to Edwards et al. (2014) who also showed that BCS gain over an eight-week winter feeding period was similar for cows offered FB or kale. They concluded that the allocation of feed was more important in determining BCS gain than the type of crop and supplement fed. This was shown in the current study where the cows fed the high allocation treatments which had higher DM intakes (Table 1), gained more BCS than those on the target treatments. This supports results of Keogh et al. (2009) who showed BCS correlated positively with forage allowance pre-partum; however, cows wintered on FB in their study had greater BCS gain than cows wintered on kale. Cows on their high FB allocation (total feed $14 \mathrm{~kg} \mathrm{DM} / \mathrm{cow} / \mathrm{d}$ ) also had higher BCS during the first five weeks of lactation, compared with the same allocation of kale (Keogh et al. 2009). A review of BCS and association with dairy cow productivity by Roche et al. (2009) concluded that cows that calve thinner than 5 to 5.5 (10-point scale) produce less milk, are likely to have extended postpartum anoestrus intervals and are less likely to get pregnant. Body condition score at calving has been positively associated with cycling by planned start of mating, and pregnancy positively associated with nadir BCS and negatively associated with BCS loss between calving and nadir (Roche et al. 2007). Although there was no effect of crop on BCS loss in the first six weeks of lactation, the higher overall BCS and higher ME intake for FB cows in the current study may partially explain the greater MS yield and improved reproductive performance (3-week pregnancy rate) of these animals.

Colostrum is essential for immunoglobulin transfer from dam to calf, with higher quality colostrum resulting in better passive transfer of immunoglobulins to the calf. There is a strong correlation between the concentration of the colostrum immunoglobulin and Brix meter reading, and colostrum Brix readings above 21-22 indicate good colostrum quality (Bielmann et al. 2010; Quigley et al. 2013). Mean Brix readings for all winter diet treatments in the current study were above this indicating that neither the winter FB or kale diet compromised colostrum quality.

Increased milk production and reproductive performance occurred despite levels of $\mathrm{P}$ and $\mathrm{S}$ in the FB-high diets falling below the recommended requirements in late pregnancy of $0.2-0.33 \% \mathrm{P}$ and
0.15-0.2\% S (CSIRO 2007; Grace et al. 2010). The potential cumulative effects of feeding winter FB diets low in these minerals and high in soluble sugars in the long term are not yet known.

\section{Nitrogen intake and environmental implications}

Although there was a trend for $\mathrm{N}$ intake to be lower for FB diets, this was not significantly different between FB and kale diets, and CP levels were above the recommended $12 \%$ for non-lactating dairy cows for all diets (DairyNZ 2017). The FB leaves had higher N content compared to the other feed components which, when combined with the $\geq 18 \%$ proportion of FB leaves in the FB diets are likely to have contributed to this. Fodder beet can absorb $\mathrm{N}$ in excess of that needed to achieve high yields, it is possible that this may have occurred with the high amount of $\mathrm{N}$ fertiliser $(194 \mathrm{~kg}$ $\mathrm{N} /$ ha) applied (Khaembah et al. 2018).

Dalley et al. (2020) showed that increasing FB from $25 \%$ of the diet of lactating cows to $40 \%$ decreased urine- $\mathrm{N}$ concentration while $\mathrm{N}$ intake was not significantly different. Reduced urination frequency and daily total urine volume have also been shown for FB, compared with kale (Ravera et al. 2015). This reduction indicates that despite the lack of a significant difference in $\mathrm{N}$ intake between the FB and kale diets in the current study it is possible that lower urine-N excretion may still occur from the FB cows, although not measured in the current study. This result would have implications for reduced impact on the environment, through reductions in $\mathrm{N}$ leaching with decreasing urine-N loading rates ( $\mathrm{Di}$ \& Cameron 2007).

\section{Conclusions}

Crop type had a greater impact on cow performance than allocation rate. The increased MS yield and improved reproductive performance shown in this study, combined with possible environmental benefits make FB an attractive winter feed. The cumulative effects on MS yield, reproductive performance and animal health of consecutive years wintering on highly digestible, high energy diets containing FB which are high in soluble sugars but low in some minerals are yet to be understood and should be the focus of future research.

\section{ACKNOWLEDGEMENTS}

This project was funded by the dairy farmers of New Zealand through DairyNZ Inc. (Hamilton, New Zealand), contract RDN1805. We would like to thank W. Ritchie and N. S. Hammond for managing data collection, the farm team at the Southern Dairy Hub for animal management and B. Kuhn-Sherlock for statistical analysis. 


\section{REFERENCES}

Bielmann V, Gillan J, Perkins NR, Skidmore AL, Godden S, Leslie KE. 2010. An evaluation of Brix refractometry instruments for measurement of colostrum quality in dairy cattle. Journal of Dairy Science 93: 3713-3721. https://doi.org/10.3168/ jds.2009-2943

CSIRO. 2007. Nutrient requirements of domesticated ruminants. Collingwood, VIC, Australia: CSIRO Publishing, $270 \mathrm{p}$.

DairyNZ. 2015. Winter crop allocation calculator. Retrieved 28 April 2020 from: https://www.dairynz. co.nz/media/2182574/winter-crop-allocation-calcmay-2015.xls

DairyNZ. 2017. Facts and Figures: a quick reference guide for New Zealand dairy farmers. DNZ30-001. $163 \mathrm{p}$.

Dalley D, Waugh D, Griffin A, Higham C, de Ruiter J, Malcolm B. 2020. Productivity and environmental implications of fodder beet and maize silage as supplements to pasture for late lactation dairy cows. New Zealand Journal of Agricultural Research 63: 145-164. https://doi.org/10.1080/00288233.2019.16 75717

Dalley DE. 2010. Achieving wintering targets - critical success factors for different wintering systems in Southland. Presented at: South Island Dairy Event (SIDE). Invercargill, New Zealand. Pp. 224-242. https://side.org.nz/wp-content/uploads/2014/05/5.3A C H IE V IN G - W IN T E R IN G - TA R GET S $\%$ E2\%80\%93-CRITICAL.pdf

Dalley DE, Geddes T. 2012. Pasture growth and quality on Southland and Otago dairy farms. Proceedings of the New Zealand Grassland Association 74: 237242. https://doi.org/10.33584/jnzg.2012.74.2870

Dalley DE, Malcolm BJ, Chakwizira E, de Ruiter JM. 2017. Range of quality characteristics of New Zealand forages and implications for reducing the nitrogen leaching risk from grazing dairy cows. New Zealand Journal of Agricultural Research 60: 319332. https://doi.org/10.1080/00288233.2017.1345762

Di HJ, Cameron KC. 2007. Nitrate leaching losses and pasture yields as affected by different rates of animal urine nitrogen returns and application of a nitrification inhibitor - a lysimeter study. Nutrient Cycling in Agroecosystems 79: 281-290. https://doi. org/10.1007/s10705-007-9115-5

Edwards GR, de Ruiter JM, Dalley DE, Pinxterhuis JB, Cameron KC, Bryant RH, Di H, Malcolm BJ, Chapman DF. 2014. Dry matter intake and body condition score change of dairy cows grazing fodder beet, kale and kale-oat forage systems in winter. Proceedings of the New Zealand Grassland Association 76: 81-88. https://doi.org/10.33584/ jnzg.2014.76.2964
Edwards J, Dalley D, Pinxterhuis J, Woods R. in press. A survey of fodder beet use and feeding practices on dairy farms in Canterbury, Otago and Southland. New Zealand Journal of Animal Science and Production 80.

Gibbs J. 2014. Fodder beet in the New Zealand dairy industry. Presented at: South Island Dairy Event (SIDE). Invercargill, New Zealand. Pp. 237-246.

Gibbs SJ, Saldias B, White J, Walsh D, Stocker N, Trotter C, Fisher B, Fisher A, Banks B, Hodge S. 2015. A comparison of liveweight gain of two groups of weaners of different entry liveweight in an ad libitum fodder beet feeding system for finishing beef cattle. Journal of New Zealand Grasslands 77: 2328. https://doi.org/10.33584/jnzg.2015.77.479

Grace N, Knowles S, Sykes A. 2010. Managing mineral deficiencies in grazing livestock. Hamilton, New Zealand: New Zealand Society of Animal Production, $204 \mathrm{p}$.

Keogh B, French P, McGrath T, Storey T, Mulligan FJ. 2009. Effect of three forages and two forage allowances offered to pregnant dry dairy cows in winter on periparturient performance and milk yield in early lactation. Grass and Forage Science 64: 292-303. https://doi.org/10.1111/j.13652494.2009.00697.x

Khaembah E, Teixeira E, Chakwizira E. 2018. Luxury nitrogen consumption by fodder beet crops. Presented at: XV European Society for Agronomy Congress. Geneva, Switzerland.

LIC. 1999. 1998-1999 New Zealand Dairy Statistics. Retrieved 10 June 2020 from: https://www.lic. co.nz/documents/486/New_Zealand_Dairy_ Statistics_1998-1999.pdf.

LIC, DairyNZ. 2019. New Zealand Dairy Statistics 2018-19. Retrieved 5 February 2020 from: https:// www.dairynz.co.nz/media/5792393/nz-dairystatistics-2018-19-web.pdf.

Nicol W, Westwood C, Dumbleton A, Amyes J. 2003. Brassica wintering for dairy cows: overcoming the challenges. Presented at: South Island Dairy Event (SIDE). Canterbury, New Zealand. Pp. 154-172.

Quigley JD, Lago A, Chapman C, Erickson P, Polo J. 2013. Evaluation of the Brix refractometer to estimate immunoglobulin $\mathrm{G}$ concentration in bovine colostrum. Journal of Dairy Science 96: 1148-1155. https://doi.org/10.3168/jds.2012-5823

Ravera B, Bryant R, Cameron K, Di H, Edwards G, Smith N. 2015. Use of a urine meter to detect variation in urination behaviour of dairy cows on winter crops. Proceedings of the New Zealand Society of Animal Production 75: 84-88. https://doi.org/10.3168/jds. S0022-0302(07)72639-5

Roche JR, Macdonald KA, Burke CR, Lee JM, Berry DP. 2007. Associations among body condition 
score, body weight, and reproductive performance in seasonal-calving dairy cattle. Journal of Dairy Science 90: 376-391. https://doi.org/10.3168/ jds.2009-2431

Roche JR, Friggens NC, Kay JK, Fisher MW, Stafford KJ, Berry DP. 2009. Invited review: Body condition score and its association with dairy cow productivity, health, and welfare. Journal of Dairy Science 92: 5769-5801.

Waghorn G, Collier K, Bryant M, Dalley D. 2018.
Feeding fodder beet (Beta vulgaris L.) with either barley straw or pasture silage to non-lactating dairy cows. New Zealand Veterinary Journal 66: 178-185. https://doi.org/10.1080/00480169.2018.1465484

Waghorn G, Law N, Bryant M, Pacheco D, Dalley D. 2019. Digestion and nitrogen excretion by HolsteinFriesian cows in late lactation offered ryegrass-based pasture supplemented with fodder beet. Animal Production Science 59: 1261-1270. https://doi. org/10.1071/AN18018 